\title{
Phosphorus Collectors from Filter Paper and Synthetic Cloth Coated with Iron or Aluminium Oxide to Provide Phosphorus by Diffusion in Soils
}

\author{
Eduardo Bernardi Luchese ${ }^{1}$, Ervim Lenzi ${ }^{2 *}$, Luzia Otília Bortotti Favero ${ }^{2}$ and Luceide \\ Heloisa Loubak ${ }^{2}$ \\ ${ }^{1}$ Department of Agronomy, Universidade Estadual do Oeste do Paraná. Rua Pernambuco 1777, CEP 85.960-000, \\ Marechal Cândido Rondon - PR, Brazil; ${ }^{2}$ Department of Chemistry, Universidade Estadual de Maringá, Av. \\ Colombo 5790, CEP 87.020-900, Maringá - PR, Brazil
}

\begin{abstract}
Phosphorus collectors made from filter paper and synthetic cloth, were tested to evaluate their feasibility of determining the need for phosphate application. The collectors were coated with two types of oxides, iron oxide and aluminium oxide. The capacity of the collectors was tested by placing them in a $2 \mathrm{~mL}$ of solution containing phosphorus $\left(\mathrm{PO}_{4}{ }^{3-}\right)$ in the concentration of 0.0, 1.00, 3.00, 5.00, 7.00, 9.00 and $11.00 \mu \mathrm{g} . \mathrm{mL}^{-1}$, respectively, after which they were placed in contact with four types of soil (LBa, LRd, LEd and Ca) and incubed for 0.0 and $24 \mathrm{~h}$. In this test the soils were kept at a humidity equivalent to $150 \mathrm{mmHg}$ suction. The amount of phosphorus extracted from the solutions was tested at intervals between 0,0 and $11.0 \mu \mathrm{g}$ of phosphorus $/ \mathrm{mL}$. Results indicated that collectors were most efficient in Dystrophic Dark-Red Latosol (LEd) and less efficient in "Bruno álico" Latosol $(\mathrm{LBa})$ and Cambisol $(\mathrm{Ca})$. Synthetic cloth was the support yielding the best performance, whereas iron oxide lining was the most adequate lining material. Phosphorus collection increased with time of incubation.
\end{abstract}

Key words: phosphorus, phosphorus availability, phosphorus diffusion, phosphorus extraction.

\section{INTRODUCTION}

Many methods have been used to determine the soil's capacity in providing phosphorus and other nutrients to plants. One of these methods is the extraction method using dilute acids. Another method which shows a better performance is the anion-exchanging resin (Raij \& Quaggio, 1981). The latter method is somewhat better than that mentioned above (Anghinoni \& Volkweiss, 1984). Tests with anionic paper, filter paper lined with iron oxide, have been brought to the attention of researchers (Gjorup et al., 1993). According to Silva \& Raij (1996), this method showed a significant correlation with phosphorus absorbed by the sugar cane plant when applied to still soil, or rather, with the paper placed in contact with the humid soil. Although not the most efficient, it presented a significant degree of improvement considering the clay factor in multiple regression analysis. No one expects that a certain method of extracting phosphorus from soil represents identically the capacity of a plant has to absorb phosphorus. New methods with universal characteristics are being tested so that losses in an increase of production through lack of fertilization or decrease of profits through excess of production may be avoided when more reliable methods are applied.

In their search for a method that better defines soil capacity to provide plants with phosphorus absorbed through diffusion, many authors tried to find a method that would define the latter factor (Silva \& Raij, 1996; Gjoroup et al., 1993; Rein, 1991). Consequently, the possibility of its usage in phosphate fertilization would be evaluated. Taking into consideration the fact that iron oxide irreversibly fixes the phosphorus through rapid kinetic reaction the above authors impregnated filter paper with iron oxide. Since iron oxide remained humid in contact with certain soils

\footnotetext{
Author for correspondence
} 
during certain periods of time, they fixed a certain amount of phosphorus. In principle this would represent the capacity of each soil to diffuse the phosphorus from a more concentrated region into a less concentrated one. Results obtained encouraged the authors to continue their analyses. The work developed by Rein (1991) was thus began, followed by research work in filter paper coated with iron oxide.

Based on these results and other works, Volkweiss and Corey (1988) in an unpublished report at the Federal University of Rio Grande do Sul, Brazil, discussed the possibility of using paper filter with iron oxide to define the necessity of phosphate fertilization.

\section{MATERIALS AND METHODS}

\section{Preparation of phosphorus collectors:}

Phosphorus collectors made from synthetic cloth received iron or aluminium oxide. The following sequence has been used for the preparation of collectors: a) cutting of cloth in $7.0 \mathrm{~cm}$ by $4.0 \mathrm{~cm}$ rectangles; b) decontamination of 4 or 5 rectangular pieces of cloth by washing with 0.2 mol. $L^{-1}$ sulphuric acid and rinsed with destilled and de-ionized water in a $100 \mathrm{~mL}$ beaker; c) distribution of decontaminated cloth on polyethylene film and drying at $45^{\circ} \mathrm{C}$; d) treatment with $1.0 \mathrm{~mL}$ of a $0.4 \mathrm{M}$ solution of $\mathrm{FeCl}_{3} \cdot 6 \mathrm{H}_{2} \mathrm{O}$ and / or $\mathrm{AlCl}_{3}$, according to the type of collector desired; e) placing of polyethylene film and rectangular cloths for drying at $45^{\circ} \mathrm{C}$; f) placing of cloth rectangles in a desiccator saturated with $\mathrm{NH}_{3(\mathrm{~g})}$ vapours (Fig. 1); the cloth rectangles are washed after a 12-hour period in the desiccator, with distilled and de-ionized water, in a polyethylene film and again dried at $45^{\circ} \mathrm{C}$; h) cutting of dried rectangles by a punch into circles with $3.00 \mathrm{~cm}$ diameter. The same procedure was used for the preparation of collectors from filter paper. Decontamination was not needed. Collectors also received $0.5 \mathrm{~mL}$ of a 0.8 mol. $\mathrm{L}^{-1}$ solution of $\mathrm{FeCl}_{3}$ or $\mathrm{AlCl}_{3}$.

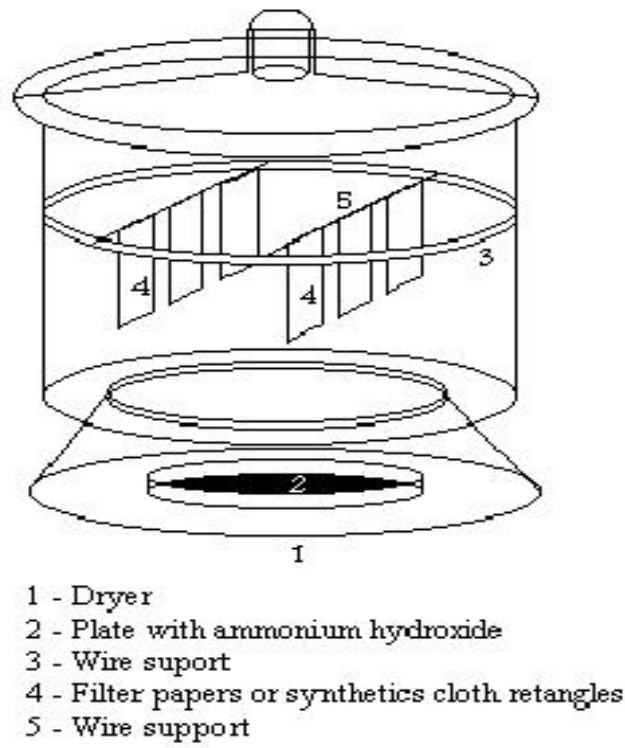

Figure 1. $\mathrm{NH}_{3(\mathrm{~g})}$ bath system used in the manufacture of collectors.

Maximum fixation of phosphorus per collector: Collectors were placed in $50 \mathrm{~mL}$ disposible cups and received a $2.0 \mathrm{~mL}$ solution of $0.0,1.0,3.0$, 5.0, 7.0, 9.0 and $11.0 \mu \mathrm{g} . \mathrm{mL}^{-1}$ of phosphorus. Five repetitions were performed during $12 \mathrm{~h}$. Collectors were then washed with $40 \mathrm{~mL}$ of distilled and deionized water.

Soils: Four types of soils, found in the state of Paraná, Brazil, were used: LRd (Dystrophic "roxo" Latosol), LEd (Dystrophic Dark-Red Latosol), LBa ("Bruno álico" Latosol) and Ca (Cambisol). Soils were dried, ground, sifted with a $2 \mathrm{~mm}$-aperture sieve and homogenized.

Procedures: Flasks of rigid plastic with $5.0 \mathrm{~cm}$ in height and $3.0 \mathrm{~cm}$ in diameter, were perforated by heated wire at the bottom with 12 small perforations. A filter paper was placed at the bottom of each flask together with a collector in a horizontal position and intercalated by two $3.5 \mathrm{~mL}$ portions of soil. Same procedure was carried for each of the type of soils, with three repetitions. Systems were placed in a Petry dish with $0.6 \mathrm{~mm}$ of destilled and de-ionized water. A certain amount of water was absorbed by the capillarity characteristic of each type of soil. Flasks were then taken to a vacuum system composed of a container for three samples (Figure 2) and linked to a $150 \mathrm{mmHg}$ suction system. 


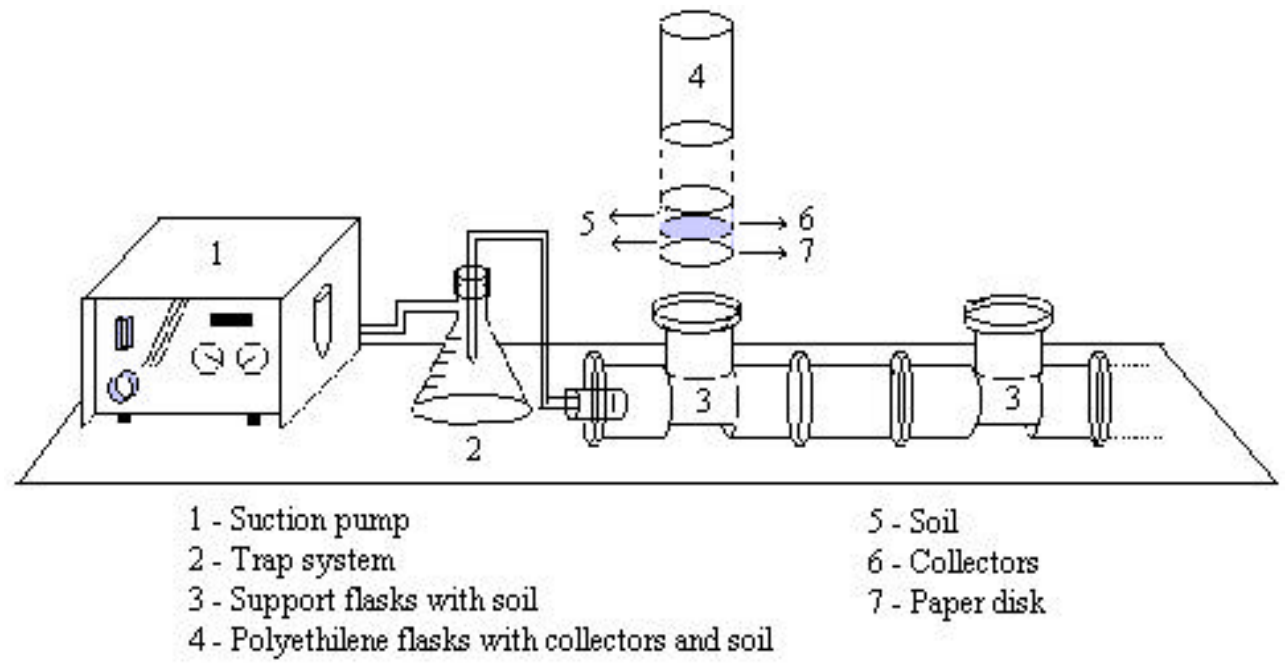

Figure 2 - Suction system with collectors in contact with soil

Suction was maintained for five minutes. Plastic flasks with collector and soil were kept still for 0 , 12 and $24 \mathrm{~h}$, respectively. Collectors were recuperated when plastic flasks were turned upside down on a clean surface. Collectors were taken out by tweezers and washed with distilled and de-ionized water from a pipette.

Analysis of phosphorus in collectors: The analytic determination of phosphorus followed the methodology of Murphy and Riley (1962) as developed by Rein (1991) and modified by the authors of this paper. $15.35 \mathrm{~g}$ of ammonium molybdate, $0.351 \mathrm{~g}$ of antimoniltartarate of potassium and $43 \mathrm{~mL}$ of $\mathrm{H}_{2} \mathrm{SO}_{4} 0.75 \mathrm{~mol} . \mathrm{L}^{-1}$ were dissolved in water up to $1 \mathrm{~L}$. At the day of the use $1.352 \mathrm{~g}$ of ascorbic acid was dissolved for each $100 \mathrm{~mL}$ of the $1 \mathrm{~L}$ solution formerly prepared.

Digestion of iron oxide of collectors impregnated with phosphorus occurred by their immersion in 2 $\mathrm{mL}$ of $\mathrm{H}_{2} \mathrm{SO}_{4} 0.75$ mol. $\mathrm{L}^{-1}$ for a period of 30 minutes in a 50-mL capacity cup. Distilled and deionized water $(8 \mathrm{~mL})$ was then added to the recipient completing the volume up to $10.00 \mathrm{~mL}$. $1.00 \mathrm{~mL}$ of the complex was added to $10.00 \mathrm{~mL}$ of this extract. The sample was ready for phosphorus determination in spectrophotometer UV-VIS adjusted to wavelength $721 \mathrm{~nm}$.
Statistical analysis: Variance analysis and Tukey's test were used for comparison of averages with SANEST sofware.

\section{RESULTS AND DISCUSSION}

Maximum fixation of phosphorus per collector: Table 1 presents the concentrations of extracted phosphorus from $2 \mathrm{~mL}$ standard solutions tested and the result of the Tuckey's test for all collectors tested. With concentration band ranging from 0.0 to $11.0 \mu \mathrm{g} . \mathrm{mL}^{-1}$, results showed that total amount of phosphorus absorbed in collectors and phosphorus concentration in the solution had a significant correlation with variation of $\mathrm{R}$ between 0.9915 and 0.9986 for tests carried out with filter papers and synthetic cloth coated with iron oxide and aluminium oxide (Figures 3,4,5 and 6).

There was no significant difference between the percentage of phosphorus submitted to a $2 \mathrm{~mL}$ phosphorus solution with concentration changing from 0.0 to $11.0 \mu \mathrm{g} \cdot \mathrm{mL}^{-1}$ for all the collectors tested. At higher concentrations, this absorption was $103.3 \%$ and $101.6 \%$ in filter paper coated with iron oxide in 7.00 and $11.0 \mu \mathrm{g} \cdot \mathrm{mL}^{-1}$ concentrations, respectively and $102.3 \%$ in synthetic cloth coated with iron oxide. The explanation of this fact may have been the 
contamination of collectors also observed through

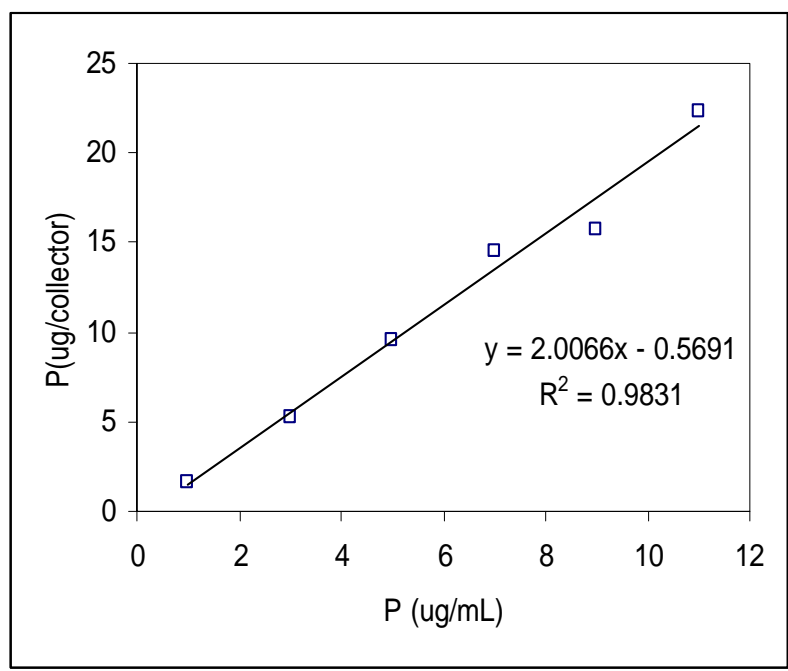

Figure 3 - Amount of phosphorus extracted from filter paper collectors coated with iron oxide when in $2 \mathrm{~mL}$ solution of phosphorus with concentrations between 0.00 and $11.0 \mu \mathrm{g} \cdot \mathrm{mL}^{-1}$.

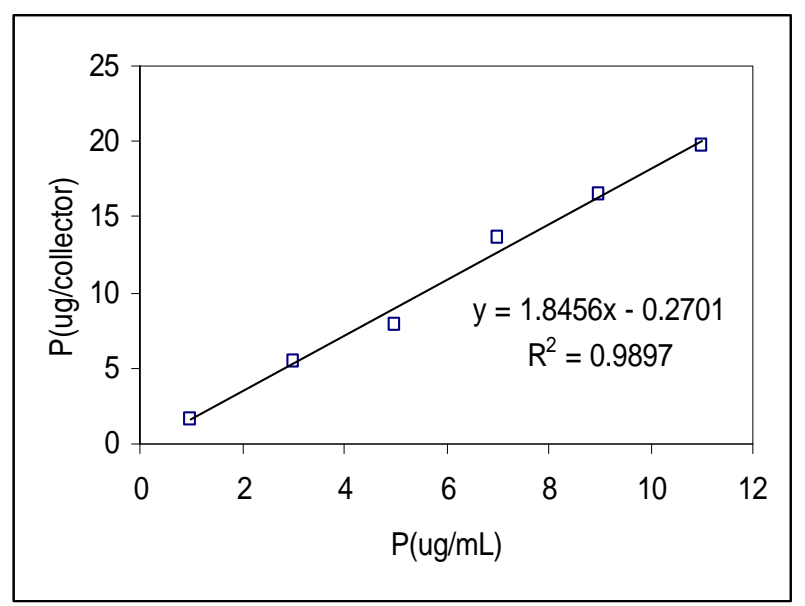

Figure 4 - Amount of phosphorus extracted by filter paper collectors coated with oxide of aluminium in 2 $\mathrm{mL}$ solution of phosphorus with concentrations between 0.00 and $11.0 \mu \mathrm{g} \cdot \mathrm{mL}^{-1}$.

When solutions presented $0.0 \mu \mathrm{g} \cdot \mathrm{mL}^{-1}$ of phosphorus, variations of standard deviations occurred at intervals between 30.9 and $49.4 \%$. Variations in samples with low quantities of $\mathrm{P}$ may be significant. Variations decrease when phosphorus concentrations are between 1.00 and $11.0 \mu \mathrm{g} \cdot \mathrm{mL}^{-1}$. standard deviations.

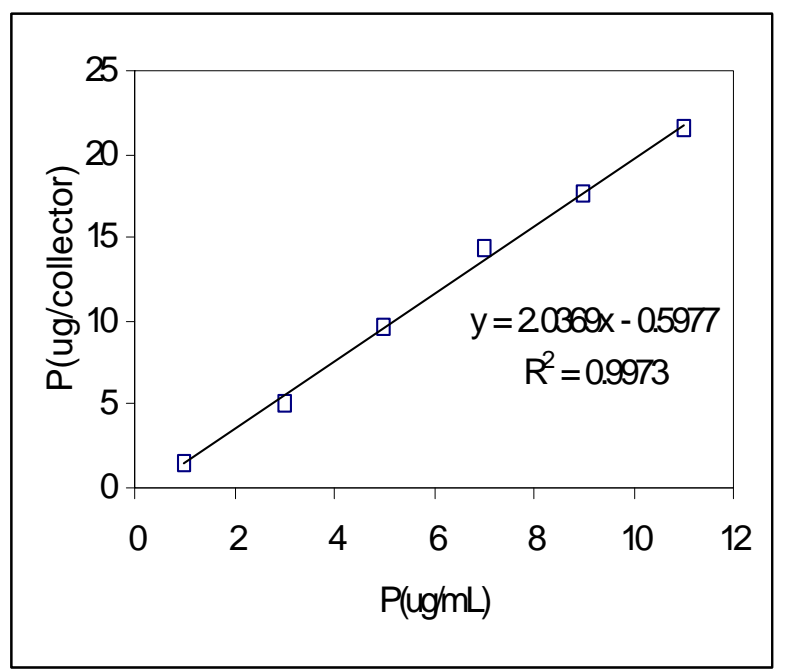

Figure 5 - Amount of phosphorus extracted by synthetic cloth collectors coated with iron oxide placed in $2 \mathrm{~mL}$ solution of phosphorus with concentrations varying between 0.00 and $11.0 \mu \mathrm{g} \cdot \mathrm{mL}^{-1}$.

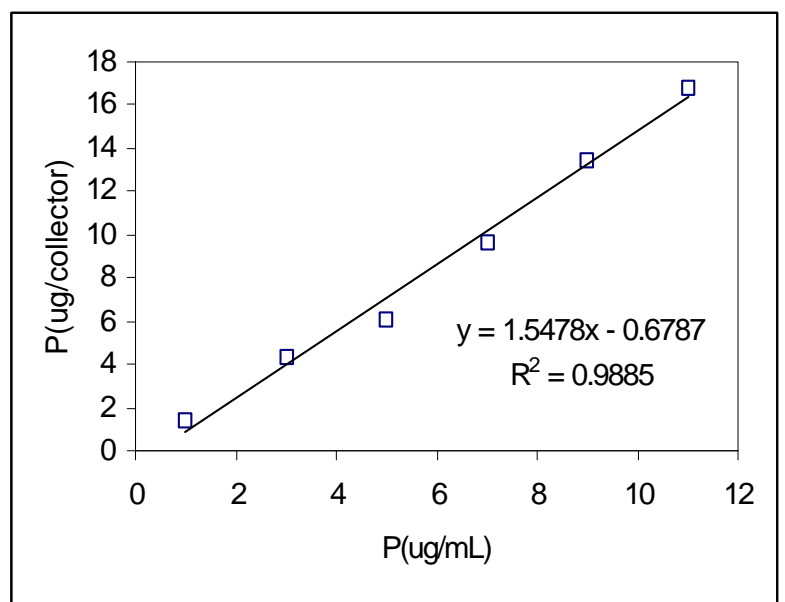

Figure 6 - Amount of phosphorus extracted by synthetic cloth collectors coated with aluminium oxide in $2 \mathrm{~mL}$ solution of phosphorus with concentrations between 0.00 and $11.0 \mu \mathrm{g} \cdot \mathrm{mL}^{-1}$.

Another factor that may be responsible for variations is the loss of small quantities of iron oxide from the external layer of the collectors during withdrawal from solution and washing of collectors. This would mostly interfere in the collectors with the more diluted solutions (Table 1). 
Table 1 - Concentration of phosphorus extracted, in $\mu \mathrm{g} /$ collector, from $2 \mathrm{~mL}$ standard solutions of 0.00 to 11.00 $\mu \mathrm{g} . \mathrm{mL}^{-1}$ by filter paper and synthetic cloth collectors coated with iron oxide or aluminium oxide and result of Tukey's test for all the collectors tested.

\begin{tabular}{|c|c|c|c|c|c|c|c|}
\hline \multirow{2}{*}{$\begin{array}{l}\text { Type of } \\
\text { collector }\end{array}$} & \multicolumn{7}{|c|}{ Concentration of phosphorus in the $2 \mathrm{~mL}$ standard solution } \\
\hline & 0.00 & 1.00 & 3.00 & 5.00 & 7.00 & 9.00 & 11.00 \\
\hline $\mathrm{pf} \mathrm{Fe}^{*} \quad(\mathrm{~m})$ & 0.1020 & 1.590 & 5.189 & 9.493 & 14.45 & 15.74 & 22.36 \\
\hline$(\sigma)$ & 0.03240 & 0.140 & 0.1520 & 0.4780 & 1.003 & 0.5970 & 1.873 \\
\hline$(\%)$ & - & $79.48 \mathrm{a}$ & $86.64 \mathrm{a}$ & $94.93 \mathrm{a}$ & $103.3 \mathrm{a}$ & $87.43 \mathrm{a}$ & $101.6 \mathrm{a}$ \\
\hline pf Al* (m) & 0.08960 & 1.597 & 5.518 & 7.857 & 13.69 & 16.45 & 19.71 \\
\hline$(\sigma)$ & 0.02810 & 0.1640 & $0, .690$ & 0.4060 & 0.9170 & 1.116 & 0.7010 \\
\hline$(\%)$ & - & $79.87 \mathrm{a}$ & $91.96 \mathrm{a}$ & $78.57 \mathrm{a}$ & $97.79 \mathrm{a}$ & $91.40 \mathrm{a}$ & $89.57 \mathrm{a}$ \\
\hline $\mathrm{px} \mathrm{Fe}^{* *(\mathrm{~m})}$ & 0.1160 & 1.529 & 5.021 & 9.691 & 14.32 & 17.62 & 21.56 \\
\hline$(\sigma)$ & 0.03590 & 0.08600 & 0.2930 & 0.7040 & 0.3080 & 1.223 & 1.873 \\
\hline$(\%)$ & - & $76.45 \mathrm{a}$ & $83.68 \mathrm{a}$ & $96.91 \mathrm{a}$ & $102.3 \mathrm{a}$ & $97.92 \mathrm{a}$ & $98.01 \mathrm{a}$ \\
\hline $\mathrm{px} \mathrm{Al}{ }^{* *}(\mathrm{~m})$ & 0.08850 & 1.357 & 4.330 & 6.061 & 9.620 & 13.42 & 16.86 \\
\hline$(\sigma)$ & 0.04370 & 0.01100 & 0.6040 & 0.8380 & 1.252 & 0.3750 & 0.9840 \\
\hline (\%) & - & $67.86 \mathrm{a}$ & $72.17 \mathrm{a}$ & $60.62 \mathrm{a}$ & $68.71 \mathrm{a}$ & $74.51 \mathrm{a}$ & $76.65 \mathrm{a}$ \\
\hline
\end{tabular}

L.D (Limit of Detection) of the used method was $0.025 \mu \mathrm{g}$ of phosphorus/collector (Welz, 1985); * - filter paper collectors with iron oxide $(\mathrm{Fe})$ or aluminium oxide $(\mathrm{Al})$; ** - synthetic cloth collectors with iron oxide $(\mathrm{Fe})$ or aluminium oxide (Al); $\mathrm{m}-$ average values; $\sigma$-standard deviations; $\%$ - percentages followed by same letter in the line do not differ among themselves at $5 \%$ by Tukey's test.

Table 2 - Tukey's test for percentages of phosphorus fixed by collectors.

\begin{tabular}{lcccc}
\hline Variation source & Repetitions & material & $\%$ of P extracted & $5 \%$ \\
\hline Matrix (collector & 12 & filter paper & 90.21 & $\mathrm{a}$ \\
$\quad$ Support) & & synthetic cloth & 81318 & $\mathrm{a}$ \\
\hline $\begin{array}{l}\text { Substrate (type of } \\
\text { oxide) }\end{array}$ & 12 & iron oxide & 92.38 & $\mathrm{a}$ \\
\hline
\end{tabular}

L.D (Limit of Detection) of the used method was $0.025 \mu \mathrm{g}$ of phosphorus/collector (Welz, 1985); Averages followed by different letters in the row differ among themselves at $5 \%$ level of significance.

Table 3 - Variance analysis for variation causes: soil (LBa, LEd, Ca, LRd)*; collectors (synthetic cloth, filter paper); coating (iron oxide, aluminium oxide) and time of incubation (0.00 - 12.0 - 24.0 hours)

\begin{tabular}{lccc}
\hline Source of variation & degree of freedom & sum of square & mean square \\
\hline Soil & 3 & 25.485 & $8.4950^{* *}$ \\
\hline Collector & 1 & 15.892 & $15.892^{* *}$ \\
\hline Type of coating & 1 & 1.9288 & $1.9288^{*}$ \\
\hline Time & 2 & 37.028 & $18.514^{* *}$ \\
\hline Soil vs. collector & 3 & 3.3584 & $1.2195^{* *}$ \\
\hline Soil vs. coating. & 3 & 11.176 & $3.7254^{* *}$ \\
\hline Soil vs. time & 6 & 9.9442 & $1.6574^{* *}$ \\
\hline Collector vs. coating & 1 & 0.24305 & 0.24305 \\
\hline Collector vs. time & 2 & 4.2299 & $2.1149^{* *}$ \\
\hline Coating vs. time & 2 & 0.86883 & 0.43441 \\
\hline Residue & 119 & 25.964 & 0.21818 \\
\hline Total & 143 & 136.42 & \\
\hline C.V. = 43.462\%; * = LBa (Latosol "Bruno álico"); LEd (Dystrophic Dark-Red Latosol); Ca (Cambisol); LRd (Dystrophic
\end{tabular}

Phosphorus extraction from filter paper and from synthetic cloth, in phosphorus solutions between 0.0 and $11.0 \mu \mathrm{g} \cdot \mathrm{mL}^{-1}$ did not have any significant difference. Both materials may be used for the manufacture of the collectors. However, the iron oxide was more efficient than aluminium oxide since the former fixed a higher phosphorus average in the solution (Table 2). Although results showed the high capacity of phosphorus fixation by collectors, these were efficacious for diluted solutions up to $1 \mu \mathrm{g}$. $\mathrm{mL}^{-1}$. It should be emphasized that the collectors manufactured with iron oxide 
presented a characteristic colour which made possible the verification of the product's quality. This did not occur with collectors with aluminium oxide and the utilization of iron oxide in the manufacture of collectors might be considered at present more adequate.

The performance of collectors in contact with the soils: When collectors were in contact with the four types of soil, to evaluate their performance, variance analysis showed significant differences with regard to soils, to collectors made from synthetic cloth or filter paper, to iron oxide or aluminium oxide coatings and to interactions: soil vs. collector; soil vs. coating; soil vs. incubation time; collector vs. incubation time (Table 3 ).

Table 4 - Phosphorus extracted by collectors with regard to soils (LBa, LEd, Ca, LRd).

\begin{tabular}{ccccc}
\hline Soil & N (repetitions) & Average & $5 \%$ & $1 \%$ \\
\hline Led & 36 & 1.6609 & $\mathrm{~A}$ & $\mathrm{~A}$ \\
LRd & 36 & 1.2840 & $\mathrm{~b}$ & $\mathrm{~B}$ \\
LBa & 36 & 0.72233 & $\mathrm{c}$ & $\mathrm{C}$ \\
$\mathrm{Ca}$ & 36 & 0.63169 & $\mathrm{c}$ & $\mathrm{C}$
\end{tabular}

L.D (Limit of Detection) of the used method was $0.025 \mu \mathrm{g}$ of phosphorus/collector (Welz, 1985); Averages followed by different letters differ among themselves at $5 \%$ by Tukey's test.

Table 5 - Phosphorus extracted from soil in $\mu \mathrm{g} /$ collector by collectors made of synthetic cloth and filter paper.

\begin{tabular}{lcccc}
\hline Substratum & N (repetitions) & average & $5 \%$ & $1 \%$ \\
\hline synthetic & & & & \\
cloth & 72 & 1.4069 & $\mathrm{a}$ & $\mathrm{A}$ \\
filter paper & 72 & 0.74254 & $\mathrm{~b}$ & $\mathrm{~B}$ \\
\hline
\end{tabular}

L.D (Limit of Detection) of the used method was $0.025 \mu \mathrm{g}$ of phosphorus/collector (Welz, 1985); Averages followed by different letters differ among themselves at $5 \%$ by Tukey's test.

Table 6 - Phosphorus extracted from soil in $\mu \mathrm{g} /$ collector by collectors with iron oxide and aluminium oxide coatings

\begin{tabular}{lclcc}
\hline Type of coating & N (repetitions) & Average & $5 \%$ & $1 \%$ \\
\hline Fe oxide & 72 & 1.1905 & $\mathrm{a}$ & $\mathrm{A}$ \\
Al oxide & 72 & 0.95901 & $\mathrm{~b}$ & $\mathrm{~B}$
\end{tabular}

L.D (Limit of Detection) of the used method was $0.025 \mu \mathrm{g}$ of phosphorus/collector (Welz, 1985); Averages followed by different letters are different among themselves at $5 \%$ by Tukey's test.
Dystrophic Dark-Red Latosol had a greater capacity in liberating phosphorus. "Bruno álico" Latosol and Cambisol were similar and both liberated the least phosphorus (Table 4).

Table 7 - Incubation time of collectors at 0.0, 12.0 and 24.0 hours

\begin{tabular}{ccccc}
\hline Incubation & $\mathrm{N}$ (Repetitions) & Averages & $5 \%$ & $1 \%$ \\
\hline 24.0 hours & 48 & 1.6457 & $\mathrm{a}$ & $\mathrm{A}$ \\
12.0 hours & 48 & 1.6457 & $\mathrm{~b}$ & $\mathrm{~B}$ \\
0.00 hours & 48 & 1.6457 & $\mathrm{c}$ & $\mathrm{C}$
\end{tabular}

L.D (Limit of Detection) of the used method was $0.025 \mu \mathrm{g}$ of phosphorus/collector (Welz, 1985); Averages followed by different letters differ among themselves at $5 \%$ by Tukey's test.

With regard to collectors made from filter paper or synthetic cloth, the latter was more efficient for extracting of phosphorus from soils (Table 5). The type of coating shows that iron oxide was more efficient in extracting phosphorus from soils (Table 6). Phosphorus collection increased with increased time of incubation (Table 7). Data indicated that the variation coefficient detected when collectors were placed in soils, $43.462 \%$ (Table 3), and showed high dispersion. Consequently, more tests are necessary to define new forms of placing collectors in contact with soils.

\section{CONCLUSIONS}

1. Tests with collectors in phosphorus solutions were efficient for intervals between 1.00 to $11.00 \mu \mathrm{g} \cdot \mathrm{mL}^{-1}$.

2. In contact with soils collectors made of synthetic cloth and coated with iron oxide were more efficient since they extract more phosphorus from the soil.

3. Collectors showed that their capacity in phosphorus collection was directly proportional to incubation time.

\section{RESUMO}

Coletores de fósforo feitos de papel filtro e pano sintético (perfex) foram usados no estudo da determinação da necessidade de adubação fosfatada. Foram preparados coletores 
impregnados com óxido de ferro e outros com óxido de alumínio. A capacidade foi testada colocando-os em $2 \mathrm{~mL}$ de uma solução padrão de fósforo (na forma de fosfato) com 0,$0 ; 1,00 ; 3,00$; 5,$00 ; 7,00 ; 9,00$ e $11 ; 00 \mu \mathrm{g} . \mathrm{mL}^{-1}$, depois foram colocados em contato com 4 tipos de solos (Lba, LRd, Led e Ca) e incubados por 0,0 e 24 horas. No teste, os solos foram mantidos com uma umidade equivalente a $150 \mathrm{mmHg}$ de sucção. Os resultados mostraram que os coletores foram mais eficientes, na extração de fósforo, no solo LED e menos eficiente no $\mathrm{LBa}$ e $\mathrm{Ca}$ (Cambissolo). O pano sintético foi a matriz (material suporte) que proporcionou melhores resultados. $\mathrm{O}$ óxido de ferro foi o substrato foi o mais adequado. $\mathrm{O}$ teor de fósforo extraído é função direta do tempo de incubação.

\section{ACKNOWLEDGEMENTS}

Grants for this research were given by $\mathrm{CNPq}$ (National Council For Research) and by the Chemistry Department of the Universidade Estadual de Maringá, Maringá, PR, Brazil.

\section{REFERENCES}

Anghinoni, I. \& Wolkweiss, S.J. (1984), Recomendações de uso de fertilizantes no Brasil [Recommendations of the use of fertilizers in Brazil]. Trabalho apresentado no Simpósio sobre Fertilizantes na Agricultura Brasileira, Embrapa/DEP Documentos, Brasília. Anais pp.179-204.

Gjorup, G.B.; Novais, R.F.; Barros, N. F. and Neves, J. C. L. (1993), Avaliação do método do papel aniônico como extrator de fósforo disponível no solo [Valuation of the method of anionic paper as extractor of disposable phosphorus in soil]. R. Bras. Ci. Solo, 17, 417-422.

Murphy J. \& Riley, J.P. (1962) A modified single solution method for the determination of phosphate in natural waters. Anal. Chim. Acta, 27, 31-36.

Raij, B. van \& Quaggio J.A. (1981), Métodos de análises de solos para fins de fertilidade [Methods of soil analysis for fertility aims]. Boletim técnico $n^{\circ} 81$. Campinas: Instituto Agronômico.

Rein, T. A. (1991) Estimativa do fluxo difusivo de fósforo nos solos e avaliação de sua disponibilidade para as plantas [Estimation of phosphorus diffusive flux in soils and valuation of its disposability] Dissertação de Mestrado, Universidade Federal do Rio Grande do Sul, Porto Alegre, Brasil.

Silva, F.C. da, \& Raij. van, B. (1996), Avaliação da disponibilidade de fósforo, por diversos extratores, em amostras de solos cultivados com cana de açúcar [Valuation of phosphorus disposability with several extractors in samples of soils cultivated with sugarcane]. R. Bras. Ci. Solo. 20, 83-90.

Volkweiss, S., \& Corey R.B. (1988) Método de extração do fósforo de solos controlada por difusão para avaliar sua disponibilidade para as plantas [Method of phosphorus extraction from soils controlled with the diffusion to evaluate its disposability to plants]. Relatório Técnico, Universidade Federal do Rio Grande do Sul, Porto Alegre, Brasil.

WELZ, B. (1985), Atomic absorption spectrometry. 2. ed. Weinheim (Germany): VCH Verlagsgesellschaft $\mathrm{mbH}, 506 \mathrm{pp}$.

Received: November 06, 1998; Revised: November 23, 1998; Accepted: October 10, 1999. 